The Third Pole: Journal of Geography

Vol. 20 - 21: 111-119, 2021

DOI: https://doi.org/10.3126/ttp.v21i01.41624

Department of Geography Education,

Central Department of Education, T.U., Kathmandu, Nepal

\title{
STATUS OF JOB AVAILABILITY FOR POSTGRADUATES IN GEOGRAPHY EDUCATION
}

\begin{abstract}
This paper attempts to analyze the situation of job availability in the markets for postgraduates, especially masters in geography education (M.Ed.). It also covers the scope of jobs in the markets, status of job involvement, and level of satisfaction based on qualitative research design and secondary data sources. Primary data were collection from interviews and discussions with teachers and postgraduate students of geography education. Secondary data were collection from various sources including digital libraries. The findings of this paper indicate that the postgraduate in Geography education is involved in different jobs such as teaching, educational research, administration, and educational planning in government, public and private sector institutions. Most of those who are engaged in teaching professions seem satisfied with their job. Besides, some private-sector workers are not happy with their work. Recently, the geography curriculum has offered geographic information systems (GIS), a global positioning system (GPS), and remote sensing (RS) as well as other tools and techniques. This may open ample job opportunities for geography graduates. The Department of Geography Education should be committed to producing skilled and competent man powers to fulfill market needs, and the government should make a policy arrangement to give priority in teaching, research, administration, and planning in education for the manpower produced in this subject.
\end{abstract}

Tej Prasad Sigdel ${ }^{1}$

Keywords: Geography education, policy arrangement, skilled human resource, global markets, job satisfaction.

\section{Introduction}

Education has been considered an essential source of knowledge, skills, and behavior for all human beings. It plays a vital role in national development in various ways. The discipline of geography offers opportunities to develop solutions to some of the

1 Sigdel is a Lecturer, Department of Geography Education, T.U. Email: sigdeltej@gmail.com 
most pressing issues for modern society, including climate change, natural disasters, overpopulation, urban expansion, and multicultural integration. Fieldwork is a helpful way of developing practical skills and gaining hands-on experience and university may also provide students with opportunities to complete work placements especially in an environmental consultant, cartographer, town planner, geographical information systems officer, conservation officer, and Other careers.

Geography education is connected to the people and environment so that it helps to perceive the skills, knowledge, and fundamental concepts. It provides opportunities to develop essential knowledge, skills, and values that enable students to become responsible citizens (Tomal, 2004). Gober, Glasmeier, Goodman, Plane, Stafford, and Wood (1995) examine employment trends in geography focused on the new supply of geographers entering the labor market related to the number of geography students. Their current specialties tell us about the types of skills and the kinds of interests to be held by future labor force entrants. In the longer term, the number of new geographers will be influenced by geographic education. Their finding shows that better geographic instruction in elementary and secondary schools will expose more students to geography as a field of study and a potential career path.

All these scholars have straightforward reality in a complex issue of job availability in the markets for graduates in geography in many developing countries including Nepal. But few scholars seem to have been involved in the study of this issue in Nepal. Amatya (1973) has shown that employment of geography graduates in various fields, such as teaching, government services, planning commission, banking, and others. $\mathrm{He}$ has shown that 54 people trained in geography have been given employment based on this subject. Now, the field of work seems to have been very scant on the subject of geography. This example indicates that the contribution of the disciplines of social sciences has given less priority to national development (Khatiwada, 2011).

Like as, Sharma (2017) has expressed that geographic knowledge starts from our home and spreads up to the universe. Whatever we do or look/listen are related to geography. Geographical knowledge is essential for rulers, administrators, farmers, students, industrialists, police, social workers, tourists and the technicians associated with roads, dams, irrigation canals, villages, and cities. Its knowledge is necessary to carry out development activities as well as to establish service centers.

Similarly, Subedi (2014) argued that no person passes a day without practicing geography. Geography is everywhere and Geographers can contribute to the governmental sector. Geographical knowledge is essential for developing countries. Geographers utilize 
their knowledge by doing surveys and solving the problems of economic crises. Thus, geographers are essential for national development.

Moreover, Sigdel (2019) mentions that Nepal is a country with many diversitiesgeographical, cultural, ethnic, and linguistic. Despite it, geographical knowledge, and skills could not be popularized in school and university. The scholars and government authorities could not realize the importance of geographical knowledge, and skills for national development. As a result, the number of students has decreased in schools and universities.

Like as, Jnawali (1995), argue that geographer in Nepal is involved in a different type of occupation. They are using their geographical knowledge and skills in the development of the nation. The potential job markets for geography education graduates are teaching, research in educational and social research. Similarly, service sectors like, government, private sectors, and non-government organizations are another job market for the graduates. In the same way, surveying and cartography, Geographic Information System(GIS), and Remote Sensing (RS) are other fields, where graduates can settle for employment opportunities.

Studies reviewed above clearly picture out that geographical knowledge and skill are essential for all and national development. Regarding the knowledge of geography, it is necessary for every citizen for national development (Awasthi, 2019). Teaching geography has given pace in less priority. Therefore, geography needs to develop as a science (Pokhare,2013). Due to these reasons high skilled geographers are not enough in Nepal (Koirala,2008).

The horizons of job market for geography graduates are very wider as compared to other social science subjects. Geographical knowledge and competencies play a vital role to develop the country. There is no doubt geography is a skill-oriented discipline. However, the attraction of majority students are tending towards technical and vocational subjects. Although, the scanty number of students are still enrolled in geography subject. It provides fewer job opportunities in the market. In this context, the number of student enrollment are fluctuating in non-technical subjects like geography. Thus, a comprehensive study requires clarifying what geography graduates perceive about the job market. 


\section{Methods and Materials}

For this paper, both primary and secondary data sources were used. Primary data were collected from interviews and interaction. Department of Geography Education was selected as research site, and twenty postgraduate students and four teachers were selected as sample population based on purposive sampling. Secondary data were collected from various sources such as published journals, research reports, books, and the internet.

\section{Result and Discussion}

Overview of Job Availability Situation in Nepal: It is challenging to seek a job after completing Masters' Level in any subject, as employment is necessary to survive. Similarly, it is related to the honor of a person as well. Due to that reason, a person searches the employment opportunity in the area of their expertise. However, many people may not get the chance that matches their academic degree. As a result, they may have been working out of their expertise about geography graduates. Regarding the scope of the job market, the perception of geography education teachers are as follow:

The potential job market for Geography Education is teaching and research. Similarly, service sectors like, government, private sectors, and non-government organizations are another job market for the graduates. In the same way, surveying and cartography, Geographic Information System (GIS), and Remote Sensing (RS) are other fields, where graduates can settle for employment opportunities. Moreover, graduates can create a job themselves starting their work related to this sector.

As mentioned above, the areas for using the knowledge and skills of Geography is too large as it is multi-dimensional subject. Specifically, this knowledge and skills can be used in governmental, non-governmental, and research areas along with teaching. But in the Nepalese context, many geography education postgraduates were not employed in their appropriate field.

Current trends of Involvements: The current trend of involvement situation of postgraduates in geography education is presented in the table below: 
Table 1: Current trends of involvement

\begin{tabular}{|l|c|c|}
\hline Types of Job & No. of Respondents & Percentage \\
\hline Teaching & 9 & 45 \\
\hline Private Sector & 5 & 25 \\
\hline Unemployed & 3 & 15 \\
\hline Retire from job & 2 & 10 \\
\hline Government Service & 1 & 5 \\
\hline Total & 20 & 100 \\
\hline
\end{tabular}

Source: Field Study, 2019.

Table 1 represents the job availability situation of postgraduates in geography education. The figure shows that they have been involved in different type of jobs, such as teaching, private sector, government services sector. The result indicates that a significant proportion of them was involved in teaching $(45 \%)$, followed by the private sector $(25 \%)$ and government services $(5 \%)$. This indicates that the education sector is the leading job market for postgraduates of geography education.

Details Job Status of Postgraduates: The details of employment area, subject, and level of respondents in teaching, as well as private sectors after completing postgraduates in geography education, is presented in table 2 .

Table 2: Details job status of geography postgraduates

\begin{tabular}{|l|l|l|l|l|}
\hline \multicolumn{3}{|c|}{ Teaching Field } & \multicolumn{2}{c|}{ Private Sector } \\
\hline Level & Subject & $\begin{array}{l}\text { No. of } \\
\text { Respondents }\end{array}$ & Area & $\begin{array}{l}\text { No. of } \\
\text { Respondents }\end{array}$ \\
\hline Secondary & Geography & 1 & Related field & 2 \\
\hline Secondary & Social studies & 3 & Unrelated field & 3 \\
\hline Basic Level & Social studies & 5 & Total & 5 \\
\hline \multicolumn{2}{|c|}{ Total } & 9 & & \\
\hline
\end{tabular}

Source: Field study, 2019.

Table 2 presents the job status of postgraduates of geography education. The figure shows that most of the products of postgraduate level have been involved in the teaching field. Among them, five persons were involved in teaching at a basic level. Likewise, three persons were involved in teaching social studies in the secondary level. Similarly, one person is teaching geography at the secondary level. Furthermore, out of five persons involved in private sector job; two persons were involved in a subject-related profession and three persons were involved in unrelated to their subject area. 
Level of Job Satisfaction: In Geography Education, various skills are taught which are practical, timely, and support livelihood. However, some graduates do not get the opportunity to utilize their knowledge and skills. Indeed, those who got chance are also not satisfied in their job. In this context the job-satisfied situation of geography, education postgraduates are given below in the tabulated form in table 3 .

Table 3: Level of job satisfaction

\begin{tabular}{|l|c|c|}
\hline Satisfaction level & No. of Respondents & Percentage \\
\hline High Satisfaction & 9 & 52.94 \\
\hline Medium Satisfaction & 5 & 29.41 \\
\hline Low Satisfaction & 3 & 17.65 \\
\hline Total & 17 & 100 \\
\hline
\end{tabular}

Source: Field study, 2019.

Table 3 shows the job satisfaction of postgraduates in geography education. As shown in the table, $52.94 \%$ of respondents are highly satisfied with their job. Especially, the respondents who are involving in the teaching field are highly satisfied. Similarly, $29.41 \%$ of respondents working in government service and private sector related to their academic degree are Medium satisfaction and $17.65 \%$ respondents who work in the private sector and it is unrelated to their academic degree is low satisfaction to their job.

Factors Affecting Job Opportunities: There is more difficult to get a job. The 21st century is the age of competition. Similarly, with long effort, geography graduates got a job. In this reference, the geography education teacher viewed that:

Job opportunity is less probable for postgraduate student of geography education in comparison to other subjects like Maths, Science, English, and Nepali. However, new and modern technologies like Geographic Information System (GIS), Remote Sensing (RS), and Global Positioning System (GPS) are also included in this course. Now, these digital technologies are demanded in the market, but we are unable to sell these digital technologies in the job market. As employers do not know modern technologies like GIS, RS, and GPS, fewer opportunities are available for the students in the markets.

The above-given statement shows that postgraduates in geography education have less opportunity to get a job. Postgraduates in geography education are difficult to get a job because of many new subjects and new inventions are coming with job opportunities. In this reference, another geography education teacher said, 
The area, to which postgraduates of geography education go after completing their degree, is the teaching profession. As geography education subject is optional at school level, it is taught in significantly few schools. So, many students of geography education are teaching Social Studies. On the other hand, the teachers who graduated in any discipline are legitimated to teach social studies. As Teacher Service Commission has asked applications from candidates of all levels for this subject, the job market for postgraduates of geography education has become even narrower. Like that, many students are unable to use theoretical matters due to the problem of language as well.

One of the respondents reported that language was a major barrier to computing in the job market while technological obstacle was another problem.

This is the era of information technology. New and modern technologies like GIS, RS, and GPS are also included in postgraduate geography education courses. These digital technologies are demanded in the market. However, the course weight is few and basic levels. So that only basic knowledge is difficult to compete in the job market.

It shows that old geography courses are not suitable for the present job market. Because the old geography courses did not focus on information technology.

\section{Conclusion}

The potential job markets of geography education postgraduates are teaching, research, service sectors, government, private sectors, and Non-government organizations. However, this study shows that most of the geography graduates are engaged in teaching sectors and few of them are involved in other jobs of private sectors.

The graduates who are involved in the teaching profession are working as social studies teachers at a different level. About job nature, most of the respondents are delighted with their job and few respondents have low happy with their job. Geography education postgraduates whose academic degree and their working field is the identical are delighted. Nevertheless, the geography education postgraduates whose working area and their academic fields are not matched to them, are low happy with their job. Many nongovernmental and private sector people do not know more about geography education, they know only geography. So that they do not prefer geography education postgraduates in their job market. They express that geography education postgraduates are related to the only teaching-learning field. Due to that, the job market of geography education is 
narrowing down as a result graduate of geography education are facing problems to get job opportunities in private sectors and non-governmental organizations. In this reference, presently available postgraduates Geographic Information System (GIS), Remote Sensing (RS), and Global Positioning System (GPS) course are based on a basic level. Due to the basic level of knowledge related to GIS, RS, and GPS, geography education postgraduates got difficulties computing the job market of private sectors. Therefore, to increase the scope of the job market for geography education postgraduates is needed to launch advanced level of GIS, RS, and GPS course. Additionally, universities and the government are required to start joint efforts to produce job market-oriented and skillful workers.

\section{Reference}

Amatya, S. L. (1974). Geography in Nepal. In Prayag Raj Sharma(Ed). Social Science in Nepal. Kathmandu: Institute of Nepal and Asian Studies, pp 1-17.

Awasthi, T. P. (2019). Challenges of geography in Nepal. The Third Pole: The Journal of Geography Education, 18-19: pp1-10.

Creswell, J.W. (2014). Educational research, planning, conducting, and evaluating qualitative and qualitative research. New Delhi: PHI Publication.

Gober, P., Glasmeier, A. K., Goodman, J. M., Plane, D. A., Stafford, H. A. \& Wood, J. S. (1995). Employment trends in geography: Enrollment and degree patterns. Professional Geographer, 47 (3), 317-128.

Jnawali, D. (1995). An attitude of different groups of people towards geography teaching: A study of Kathmandu district. Research Report submitted to the Research division, TU.

Jnawali, D. (2001). Nepalma Bhoogol Shiksha : Pathyakaram, Pathyapustak ra Shikshan (Geography Education in Nepal: Curriculum textbooks and teaching), Education Innovation (a publication on the educational issue), Kathmandu: Center for Educational Innovation and Research (CEIR), 1, pp117-129.

Jnawali D., Poudel, K. P., Rijal, S. P., Dhakal, K. R., Awasthi, T. P., \& Sigdel, T. P. (2014). Geography education in Nepal: A study of status and challenges. A Research Report submitted to University Grants Commission, Nepal.

Khatiwada, S.P. (2011). Teaching geography contents in social studies: Perspective on teaching-learning activities. Nepalese Journal of Educational Studies, 1, pp107-112.

Koirala, H. L. (2008). Geography in Crisis: Is geography in Nepal an exception? Geographical Journal of Nepal, 6. pp 31-44. 
Tej Prasad Sigdel / Status of Job Availability for Postgraduates in Geography Education \|119\|

Pandey, R. K. (1998). Pioneers of Nepalese geography: Geography and geographer in Nepal. Vol 1. pp 9-10, Kathmandu: Centre for Nepalese Geography.

Pokhrel, K.P. (2013). Geography education and research in Nepal: Challenges, status, and options. The Third Pole, The Journal of Geography, 13, pp 39-45.

Pokhrel, R.P. (2006). Geography teaching issues and challenges. In Subedi, B.P, Poudel, P.C and Poudel K.P. (eds.), Processing of the National Conference on Geography in Nepal: Mountain Environment and Human Activities. Kathmandu: Central Department of geography, Nepal Geographical Society and National Centre for Competence in Research, pp 115-121.

Pradhan, P. K. (ed.), (2009). Geographic research methods handbook. Kathmandu: Central Department of Geography, T.U.

Sharma, P. (2017). Geography: Why not study. Kathmandu: Shashika Monthly.

Sigdel, T. P. (2019). Utilization of Geographical knowledge and skills: A study of M. Ed geography graduates. Unpublished Research Report submitted to the Faculty of Education, Dean's Office.

Subedi, B. P. (2005). A glimpse of geographic research in Nepal: Review and reflection. In Subedi, B.P. and Poudel, P.C.(eds.), Geography and Geographers work in Nepal: Reflection on Mountain Environment and Human Activities. Kathmandu: Central Departments of Geography, Nepal Geographical Society and NCCR north-south, pp 85-103.

Subedi, B. P. (2014). The state of geography teaching and research in Nepal: A review and reflection. Kathmandu: Martin Chautari.

Tomal, N. (2010). High school students' attitude towards geography and the question that they wonder about it. Retrieved on June 12, 2016, from http//www. academicjournal.org/sre.

https://www.etymonline.com/word/geography.

https://www.topuniversities.com/student-info/careers-advice/what-can-you-dogeography-degree 